International Journal of Instruction e-ISSN: 1308-1470 • www.e-iji.net
July $2019 \bullet$ Vol.12, No.3

p-ISSN: 1694-609X

pp. $1-16$

Received: 04/09/2018

Revision: 01/02/2019

Accepted: 08/03/2019

OnlineFirst:05/04/2019

\title{
Evaluating the Use of Modern Indonesian Literary History Textbook (Poetry in East Java) in Teaching Literary History Course
}

\section{Sutrimah}

A Post-Graduate Student of Sebelas Maret University of Surakarta, Indonesia, sutrimahyusuf@yahoo.com

\section{Retno Winarni}

Prof., in Indonesian Language Education of Sebelas Maret University of Surakarta, Indonesia, winarniuns@yahoo.com

\section{Nugraheni Eko Wardani}

A Senior Lecturer of Sebelas Maret University of Surakarta, Indonesia, nugraheniekowardani_99@yahoo.co.id

\section{Ngadiso}

A Senior Lecturer of Sebelas Maret University of Surakarta, Indonesia, ngadisodok@yahoo.com

This study aimed at (1) revealing the lecturers and students' perception on the use of modern Indonesian literary history textbook in teaching Literary History course; and (2) evaluating the effectiveness of modern Indonesian literary history textbook in teaching Literary History course. This study combines evaluative descriptive research designs and experimental design with a mixed method approach to evaluate the history of modern Indonesian literary history textbooks in private universities in East Java, Indonesia. The data collection were carried out through documentation, observation, interviews, and test. Before the instruments were used, the validity and reliability tests were employed. The sampling technique used for the interview was purposive sampling. While for choosing the experimental and control group from each university, the sampling technique used was cluster random sampling. Since there were qualitative and quantitative data, the qualitative data were analysed descriptively and the quantitative data were analysed by using t-test. The results reveal that both the lecturers and the students from each university responded positively towards the use of modern Indonesian literary history textbook in teaching Literary History course.

Keywords: literary history, textbook material, poetry, teaching, literary history course

\section{INTRODUCTION}

Citation: Sutrimah, Winarni, R., Wardani, N. E., \& Ngadiso (2019). Evaluating the Use of Modern Indonesian Literary History Textbook (Poetry in East Java) in Teaching Literary History Course. International Journal of Instruction, 12(3), 1-16. https://doi.org/10.29333/iji.2019.1231a 
The learning process is successful if it is supported by adequate facilities and infrastructure, such as rooms and other supporting facilities. A textbook is one of the facilities that is pivotal learning process. Sheldon (1988) asserts that students use textbooks to reinforce their learning process and get information. Moreover, teachers use textbooks to teach and facilitate learning. However, a textbook which is suitable for both students and lecturers' is not easy to find. Preparing a textbook is certainly not an easy job. The textbook is a combination of competencies that students achieve by the course.

A textbook is a-part of the learning devices needed by students. Cunningsworth (1995) points out that textbook is a valuable resource for self-directed learning, an effective resource for teacher to present material, a source of ideas and activities, a reference source for students, and syllabuses. Referring to a literary history course, there are some textbooks which are common, such as satra baru indonesia $i$ by a. Teeuw (1980), sastra indonesia modern ii by teeuw (1984), sejarah sastra indonesia modern and kitab sejarah sastra indonesia by yant mudjianto and amir fuadi (2008). Those books simply discuss the history of modern Indonesian literature in the national frame. For this reason, it is necessary to develop a literary history textbook for modern Indonesian literature which contains specific material and will have great benefits for literary history courses. The specific material will be more interesting if it relates directly to the state of the student. Cunningsworth (1995) considers that the evaluation of the textbooks needs the most successful and effective procedures in relation to users' views. So it is very important to develop a literary history book of modern Indonesian literature with the specific material. The development of textbooks must be related to the curriculum, the syllabus and the lesson plan.

In this case, the works of east java poets can be used as textbook material in literary history courses. Thus, it is very important to include poems by east java poets as part of the history of the nation to make clearer that east java has also produced poets.

The wide use of textbooks to teach literary history course in Indonesian classrooms is understandable given the fact that a, "textbook materials in not simply the everyday tool of a teacher; it is an embodiment of the aims, values, and methods of the particular teaching/learning situation" (hutchinson, 1987). Leipei to achieve the proficiency level required, textbooks, must include authentic material. It is therefore of main importance for us to evaluate the newly written textbook (modern Indonesian literary history textbook: poetry in east java) to teach literary history in a feasible and effective way.

\section{LITERATURE REVIEW}

\section{The Use of Textbooks in Teaching and Learning Process}

Textbooks are learning tools that students need to have in learning activities. This is because textbooks can help them to directly learn the learning materials. Therefore, the existence of textbooks is pivotal for lecturers and students. According to O'Neill (1982, p.105), there are four reasons why the teacher needs to use the textbook in teaching and learning process, i.e. (1) a great deal of the material which was very suitable for their needs, (2) the textbooks made it possible for the teachers and students to look ahead to 
what they were going to do or to look back at what they have done, (3) the textbooks provided materials which were well-presented, (4) the textbooks allowed them to adapt and improvise while they were teaching and learning.

The textbook is very important in situations where changes in the teaching approach take place since it can introduce changes in the landscape within a structured framework enabling both teachers and learners to develop in harmony with the introduction of new ideas (Hutchinson \& Torres, 1994). Furthermore, the textbook is pivotal to support teaching and learning processes as many experts have investigated. Dealing with this statement, Hutchinson \& Torres (in Litz, 2012, p.5) state that:

"The textbook is the almost universal element of teaching. Millions of copies are sold every year, and numerous aid projects have been set up to produce them in countries ... No teaching-learning situation, it seems, is complete until it has its relevant textbook".

Tarigan and Djago (1986, p.67) states that textbook is the record of rational mind arranged in a book form to achieve certain instructional goals in learning. Textbooks need to present a sequence of thoughts that are coherent in order to help in achieving learning goals. Thus, textbooks must present content that is easily understood by the reader.

Meanwhile, in Minister of National Education Regulation No. 2 of 2008 Article 1 paragraph 3, it is mentioned that:

"Textbooks are compulsory reference books used by education units or universities that contain learning material in order to increase faith, piety, noble character, and personality, mastery of science and technology, increased sensitivity, and aesthetic abilities, enhancing kinaesthetic abilities, and health compiled based on national education standards".

Furthermore, textbooks can be used as a media of materials enrichment at schools (Trihartati, 2010). According to Rifai (2010), the textbook is a book that is used to study or explore a subject of knowledge, science, technology, and art so that it contains a presentation of the principles of scientific work and literary related to it.

Textbooks are very dominating in learning. Therefore, textbook writers must understand the basics of the curriculum used by textbooks in order to facilitate lecturers in the learning process. Lecturers and students must be aware of the importance of textbooks in the learning process because the existence of textbooks will facilitate students' understanding of the basic competencies that will be mastered.

A good textbook must have special sensitivity to know every change that occurs in the curriculum. If it is ignored, the curriculum objectives will be difficult to realize in the learning process. The fact is that lecturers are closer to textbooks than the curriculum itself. Whereas the textbook used must be in harmony with the existing curriculum. This means that there must be a match between the contents of the curriculum and textbooks.

The existence of textbooks, as teaching materials, must be able to communicate the contents according to the needs of students. Textbooks are required to be able to provide 
new knowledge and thoughts for students (Rifai, 2010). Meanwhile, according to Tarigan, et al., (1986) the closeness of textbooks with curriculum can be illustrated as the relationship between fish and water, fish with cliffs, or also can be illustrated as two sides of a coin, two but one, one but two. This understanding requires that all planning and business activities carried out by the textbook writer must refer to the current curriculum.

Suryaman (2012) states that textbooks must meet the following criteria: 1) have a clear and up-to-date point of view and applicable; 2) have adequate material content, full of experience, variety, easy to read, and able to arouse and increase students' interest; 3 ) have a systematic and gradual method of preparation that takes into account the ease of understanding, the existence of sufficient explanation, the existence of systematically organized illustrations, and straightforward disclosure; 4) have the possibility of presentation with methods and means that stimulate students to be interested in reading it; 5) have enough depth to be able to guide students to solve problems in the field well; 6) have an evaluation tool that enables student competency to be measured in certain fields; and 7) have the potential to attract the students to study in the field deeper.

Dealing with the advantages of using textbooks in teaching and learning process, the followings are the most frequently stated advantages of using textbooks (Graves, 2000; Basturkmen, 2010):

1. It provides a syllabus for the course because the authors of the syllabus have made decisions about what will be learned and in what order.

2. It provides security for the students because they have a kind of roadmap of the courses: they know what to expect and they know what they are expected from them.

3. It provides a set of visuals, activities, readings, etc., and so save the teacher's time in finding or developing such materials.

4. It provides teachers with a base for assessing student learning. Some textbooks include tests or evaluation tools.

5. It may include supporting materials (teacher's guide, CD, worksheets, and videos)

6. It provides consistency within a program across a given level if all teachers use the same textbook. If textbooks follow a sequence, as within a series, it provides consistency between levels.

Besides, the textbook also has limitations, which can lead to teacher's and learner's dissatisfaction with the course. The following list contains the most frequently stated disadvantages of using only ready-made textbooks (Graves, 2000; Basturkmen, 2010):

1. The content or examples may not be relevant or appropriate to the group and may not reflect the students' needs since textbooks are often reflected in the interests and needs of students. 
2. They may contain inauthentic language since texts, dialogs and other aspects of content tend to be specially written to incorporate teaching points and are often not representative of real language use.

3. The content may not be the right level.

\section{Literary History as a Basic Subject/Course}

In the Indonesian Language Education study program curriculum in several universities in Indonesia, literary history courses are basic subjects of literary science that must be taken. This is because, in the context of literature, the history of literature is one of the three branches of literature, in addition to literary theory and literary criticism (Wellek \& Warren, 1990). Literary history studies the development of literature produced by a society or nation. In the Indonesian context, literary history studies the development of Indonesian literature. Through literary history, students will understand what works have been produced by a particular community or nation, who are the authors, and what issues are written in the literary works.

The word 'modern' for modern Indonesian literature is used to show the intensity of Western authors in the development and literary life of the time. Then Indonesian literature refers to the medium of language used (Indonesian) and the style of the contents of the essay reflects the attitude of the Indonesian character in looking at a problem.

When it is viewed from the periods, the modern Indonesian literary history was begun in the 1920s, after Classical Malay literature. This happened because at that time the work that was born was the work of Indonesian literature as was the characteristic of modern Indonesian literary works such as the use of language and the content of stories. Rosidi (1968) said that around the 20th century, the leaders and fighters began to realize their weaknesses and the strengths of their opponents, giving rise to a sense of common sense. This gave rise to a sense of nationalism and had an impact on literary development at that time.

According to Sudarmoko (2009), in the transition period from old literature to modern literature, if it exists, it is limited and marked by respect for the names of previously anonymous authors, media publications, forms of education and western knowledge, and the influence of western literary works. Thus, modern Indonesian literature provides clear boundaries to literary works at that time. Whereas Sarwadi (2004, p.8-10) said that Indonesian literature is a literary written in Indonesian which exudes the attitude and character of the Indonesian people. Based on the explanation above modern Indonesian literature is literature written in Indonesian, the content of which exudes the attitude and character of the Indonesian people by respecting the names of previously anonymous authors, media publications, forms of education and western knowledge, and the influence of western literature, in 1920- after classical Malay literature. Thus, the history of modern Indonesian literature attaches great importance to language and style of content which is a reflection of the culture of the Indonesian nation. 


\section{Poetry as a Part of Literary Works}

Poetry as a literary work is a wholeness totality which has certain characteristics, i.e. (1) the existence of rules and sequences (Order), (2) the existence of complexity, (3) the existence of unity, (4) and coherence (5) and serves to purify the human soul or catharsis (Luxemburg, 2008). This is in line with Siswantoro's (2010) view in which poetry is a language that is organized by rules, messages or information is packaged more artistically. Poetry has an organized language and contains a message to the audience, besides the language used must also have a beauty value compared to other forms of literary work.

Some literary experts give limitations to poetry related to the extrinsic elements; some others also give limitations to poetry related to intrinsic elements. But some of them also give limitations to poetry related to both extrinsic and intrinsic elements. Waluyo (2010), states that poetry is a literary form that expresses the thoughts and feelings of poets imaginatively and is composed by concentrating all the power of language in its physical structure and inner structure.

In line with Waluyo (2010), and Boulton, (1979, p.7) divides the structure of poetry into two parts, i.e. the physical form and the mental form of poetry. The physical form is the appearance on paper, and more important, the sound of poetry. It may be either the sound when poetry is read or the sound we hear when we read it to ourselves. It includes rhythm, rhyme, intonation and various kinds of echo and repetition. The mental form can be described as content in the usual sense of the word when applied to literature: it includes grammatical structure, logical sequences, the pattern of associations, the use of a dominant image, the pattern of image and emotion.

Meanwhile, Reeves (1998) says that a poem is not a bird's song, any more than it is a rose, but if it is not something of this quality of self-sufficiency; it is not a true poem and might as well have been presented as prose. So what is meant by poetry is not a melodious word reading as the song of a bird's voice but in the form of the presentation of words such as prose. Atmazaki (1993), states that poetry is a certain beauty and atmosphere contained in words.

Furthermore, Noor $(2009$, p.21) argued that the limits of poetry are literary works that use distinctive language, not common or ordinary language. The language used in poetry is effective and sometimes suggestive, so as to make anyone who enjoys it carried away in the atmosphere in the content of poetry. A poem is also often accompanied by imagination because an imagination is an experience in imagining an intentional action done consciously about objects in the real world when the real object is not in place.

Sastri (2013) argues that the most important thing to create a poem is imagination because with that imagination a new world can be created as an interesting and most important object in a poem. Imagination is essentially vital in the sense that it informs and animates other existences. A poem is often accompanied by imagination because an imagination is an experience in imagining a deliberate/conscious act of things in the real world when the real object is not in place. 
"In imagining experience as an intentional act of consciousness, when objects are not present or when we imagine things that don't refer to any real objects in the world, this is mostly the case of images in poetry" (Zalipour, 2010, p.112).

Kennedy (1971) states that a poem is a rhythmic word composition that expresses behavior, and is compiled to make someone else amazed and amused and emotional response analysis. Dealing with the response, emotion is also related to the meaning of poetry. Furthermore, Perrine (1974) states that the meaning of a poem is as follows.

"Poetry is as universal as language. The most primitive people have used it, and the most civilized people have cultivated it. In all ages and in all countries, poetry conditions of people, by soldiers' statesmen, lawyers, farmers, doctors, scientists, clergymen, philosophers, king, and queens. In all ages, it has been to children. Because it has given pleasure. People have read it or listened to it or recited it because they liked it because it gave them enjoyment".

\section{Research Questions}

From the background of the research above, the researcher formulates the statement of problems as follows.

1. How is the lecturers and students' perception of the use of modern Indonesian literary history textbooks (Poetry in East Java) in teaching literary history course?

Is the use of modern Indonesian literary history textbooks (Poetry in East Java) more effective than the use previously common textbook used in teaching literary history course?

\section{METHOD}

\section{Research Design}

This study combines evaluative descriptive research designs and experiments with a mixed method approach to evaluate the history of modern Indonesian literary history textbook (poetry in East Java) in private universities in East Java, Indonesia. The evaluative descriptive design was used to reveal the lecturers and students' perception of the use of modern Indonesian literary history textbook (poetry in East Java) in teaching Literary History course. The experimental design used in this study was to evaluate whether or not the use of modern Indonesian literary history textbooks (Poetry in East Java) is more effective than the use of previously common textbook used in teaching literary history course. The experimental design used in this study was the study group design proposed by Fraenkel and Wallen (2012), there are two trials groups, experimental and control groups.

\section{The Population and Sample}

The population of this study was students of the Indonesian Language and Literature Education Study Program in Private Universities in East Java. The subjects in this study were the first-semester students majoring in Indonesian language education at UNISDA (Islamic University of Darul Ulum) Lamongan, IKIP PGRI (Institute of Teacher 
Training and Education of PGRI) Bojonegoro, UNIROW (PGRI University of Ronggolawe) Tuban. There were two kinds of sampling techniques used in this study, i.e. purposive sampling and cluster random sampling. The purposive sampling technique was used to choose the sample for the interview. The criteria for this purposive sampling were those who have high, medium, and the low score in their Literary History course from each university. Then, the cluster random sampling was used to choose the sample for the experimental and control group from each university. Hence, in this study, there were two classes from each university, one class was an experimental group and another was as the control group. Therefore, there were 6 classes altogether. The total number of students is 82 .

\section{Research Instruments}

\section{Documentation}

In this study, the initial data was taken from the results of the student's daily test scores. This was done to find out the students' initial abilities about Literary History in the material of poetry in East Java. This initial data, then, was analysed by using the t-test to know whether or not the classes are in balance condition. This balancing test is important in the experimental design. This process was done initially before the treatment was given to the experimental and control group. This balancing test was done to ensure the researchers that the students' improvement was because of the treatment itself, not because of other factors such as the different abilities between the two groups.

\section{Observation}

Observations were made to determine the learning process of literary history courses. This was done to get clear information about the response of the students and lecturers on the use of modern Indonesian literary history textbook (poetry in East Java) in teaching Literary History course.

\section{Interview}

Interviews are used to gather as much information as possible, in-depth, and accurate, about the lecturers and students' perception on the use of modern Indonesian literary history textbook (poetry in East Java) in teaching Literary History course. The interviews were addressed to the Chair of the Study Program, lecturers of literary history courses (8 lecturers altogether), and students. The interview guide consists of open questions related to the use of modern Indonesian literary history textbook (poetry in East Java) in teaching Literary History course.

\section{Post Test}

The post-test was conducted to determine the differences in students' abilities between the experimental and control groups after the treatment. This post-test was done in order to evaluate whether or not the use of modern Indonesian literary history textbooks (Poetry in East Java) is more effective than the use previously common textbook used in teaching literary history course. In this post-test, the researcher used multiple choices. The instrument of multiple choice questions was first tried out in a non-sample class, 
then, the results were analyzed for its validity and reliability. After the instrument was statistically valid and reliable, the instrument was ready to use for post-test (used to test the students in experimental and control groups after the treatment).

\section{Validity and Reliability of the Instruments}

Validity and reliability are very important to determine the feasibility and usefulness of an instrument. Validity and reliability test for interview guideline and observation checklist in this study was done through expert judgment, and all valid questions are stated. Meanwhile, the validity test for multiple choice questions was done by using point biserial correlation coefficient $\left(\mathrm{r}_{\mathrm{pb}}\right)$ and the reliability test was done by using the KR 20 formula (Kuder Ricardson). Dealing with the multiple choice questions, it was found that there were 25 are questions are valid and reliable. Those 25 -questions, then, were used for the post-test.

\section{Triangulation Technique}

As it is mentioned previously, in this study, there were two kinds of data, i.e. qualitative data and quantitative data. The qualitative data was dealing with the lecturers and students' perception and responses on the use of modern Indonesian literary history textbook (poetry in East Java) in teaching Literary History course. The qualitative data yielded from this study was also triangulated to check the validity of the data. In this study, the triangulation process was done by comparing and analyzing simultaneously the results of observation (observation checklist and field notes) and the results of the interview.

\section{Research Procedures}

First, the researcher used the documentation of the results of the previous test scores to find out the initial conditions of the students. In an experimental design, the samples, in this case is experimental and control groups, must have the same starting point (balance condition). After that, the researchers gave the two groups with different treatment in Literary History course. The experimental group was taught using modern Indonesian literary history textbook (poetry in East Java). On the contrary, the control group was treated by using the previously common textbook used by the lecturers. During the implementation, the experimental group was observed. This observation was mainly focused on the lecturers and students' response to the use of modern Indonesian literary history textbook (poetry in East Java) in teaching Literary History course. After six meetings, the two groups were given a post-test. After giving post-test, the researchers also conducted the interview to lecturers and students dealing with their response and perception on the use of modern Indonesian literary history textbook (poetry in East Java) in literary history class.

\section{Data Analysis}

There were two kinds of data in this study, qualitative and quantitative data, since this study combined evaluative descriptive research designs and experiments with a mixed method approach. Therefore, in data analysis, the researchers implemented two different techniques. The first technique was descriptive analysis, in which it was used in order to 
analyze the qualitative data. This qualitative data was used to reveal the lecturers and students' perception on the use of modern Indonesian literary history textbooks (Poetry in East Java) in teaching literary history course. The second technique was t-test analysis. This $t$-test was used to analyze the quantitative data in which its purpose was to reveal the effectiveness of modern Indonesian literary history textbooks (Poetry in East Java) used in teaching literary history course

\section{FINDINGS}

The Lecturers and Students' Perception of the Use of Modern Indonesian Literary history textbook (Poetry in East Java) in Teaching Literary History Course

To reveal the lecturers and students' perception on the use of modern Indonesian literary history textbook (poetry in East Java) in teaching Literary History course, the researchers used two techniques, i.e. observation during the experimental class happened and interview to lecturers and selected students. From the observation and field notes, it was found that the lecturers and students responded positively on the use of modern Indonesian Literary history textbook (Poetry in East Java) in teaching Literary History course. The students have enthusiastically followed the lesson given. The students have a high interest and motivation. Moreover, the students were asked to learn in a group, based on the instruction in the textbook. In group learning, all group members play an active role. Students discussed East Java poetry and poets based on the textbook. They also asked the lecturers if there were things that were poorly understood and unclear. After grouping and discussing, students have notes about poetry and poets of East Java. Thus, students will have an understanding and knowledge of poetry and poets in East Java. Besides, the lecturers also easily delivered the materials to the students since the materials have been organized well in the textbook.

Based on the results of the interview with lecturers, it was revealed that the use of modern Indonesian Literary history textbook (Poetry in East Java) in teaching Literary History course could stimulate effective learning for students because students were made in groups then they discussed poetry and poets of East Java. Further, another lecturer stated that in the learning process, the students were very enthusiastic and motivated. This is because they can know poets who have been far from their neighborhood. Then, they were also very proud of being able to know poets from East Java.

The enthusiasm and motivation of students in the literary history course are quite high because they can create moments. Moments must be created by the lecturer, and it can be begun with simple things like learning with group discussions. Daily events must be an interesting experience, which can be an inspiration for students. Students feel happy; happiness in learning literary history will foster a love of literary works especially poetry. In lectures, the lecturers are not just teaching, but are able to encourage students to have a love for Indonesian literary works, especially literary works that are very close to the environment they live. Modern Indonesian literary history textbooks (poetry in 
East Java) are able to create a sense of love and motivation for students to study literary history courses.

(Respondent 3)

Further, respondent 2 stated that the learning of literary history course by using modern Indonesian literary history textbook (poetry in East Java) could encourage students to study literary history course, especially dealing with the works that had been produced by some poets in East Java. It also assists the lecturer to introduce poetry in East Java to the students.

Very good, mom, it can help lecturers to introduce the East Java poetry to the students. As we are the people of East Java, so, we have an important role to introduce it. Besides, this textbook can motivate the students to learn literary history, especially those focusing on East Java poetry.

(Respondent 2)

Some interviews with students were also conducted to know the students' perception. Based on the results of interviews with students on the use of modern Indonesian literary history textbook (poetry in East Java), respondent 1 stated that he was very happy to learn literary history because he knows not only the poets from East Java but also the poetry that had been produced. Respondent 1 also said that he was very interested in the poem from Zawawi Imron, entitled 'Mother' in which it is one of the poetry that is included in the modern Indonesian literary history textbook.

I was very happy to study literary history course using the modern Indonesian literary history textbook (Poetry in East Java). I knew the poets from East Java, the place where I live now. I was very interested in Zawawi Imron's poem entitled 'Mother', the language was very good, especially how to describe my mother as someone who was very special whose position was the highest of anything; it seems that I was affected when I read it over and over.

(Respondent 1)

Then respondent 2 stated that learning of literary history by using modern Indonesian literary history textbook (poetry in East Java) can raise the motivation of learning literary history because it specifically discusses poetry in East Java.

when I was taught with this modern Indonesian literary history textbook (Poetry in East Java), I feel more motivated and easier to understand the contents of the book

(Respondent 1)

Meanwhile, respondent 3 also gave a response almost similarly with respondent 1 and 2 . Respondent 3 stated that the modern Indonesian literary history textbook (poetry in East Java) is very suitable for learning literary history course. This textbook is suitable to teach students, especially those who are majoring in Indonesian language education, to be more familiar with literary works. 
I am very happy with the textbook, with that book I can easily recognize and understand East Java poetry and poets. I think it is suitable for the students majoring in Indonesian Language Education.

(Respondent 3)

\section{The Effectiveness of Modern Indonesian Literary History Textbook (Poetry in East Java) in Teaching Literary History Course}

\section{Initial Data}

To know the effectiveness of the textbook, the researchers used a t-test formula for analysis. Since this stage used an experimental design, the students' condition must be the same between the two groups, experimental and control groups, before the treatment was implemented. To know the students' initial condition, the researchers used the documentation in the form of the previous score of the students in the literary history course. The data is presented in the following table.

Table 1

The summary of initial data (The Previous Data)

\begin{tabular}{llllll}
\hline \multicolumn{1}{c}{ Class } & $\mathrm{N}$ & Mean & $\mathrm{S} 2$ & X Max & X Min \\
\hline Experimental & 44 & 48.6364 & $30.655 \%$ & 60 & 40 \\
Control & 38 & 49.2632 & $44.469 \%$ & 65 & 40 \\
\hline
\end{tabular}

The data, then, were tested for its normality and homogeneity. The normality test used Lielifors formula and the homogeneity test used Bartlett formula. After that, the data was analyzed by using the $t$-test for a balancing test. The results are presented in the following table.

Table 2

The summary of the t-test for the balance test

\begin{tabular}{llllll}
\hline$t$-test & Degree of Freedom & alpha & T-table & T-obs & Conclusion \\
\hline $\begin{array}{l}\text { Control and } \\
\text { experiment class }\end{array}$ & $(38+44-2)=80$ & $5 \%$ & 1.9893 & 0.4650 & $\begin{array}{l}\text { Ho accepted (the } \\
\text { data is balance) }\end{array}$ \\
\hline
\end{tabular}

From the table 2 above, it is clearly seen that t-obs is lower than t-table. It means that there is no significant difference between the experimental and control groups. In other words, the two groups are in balance condition and have the same starting point.

\section{Post-test Data}

After the two groups were treated by using different treatments for 6 meetings, the two groups were then tested for an understanding of poetry in East Java. The post-test results are presented in table 3 below:

Table 3

The summary of post-test data

\begin{tabular}{llllll}
\hline Class & $\mathrm{N}$ & Mean & S2 & X max & Xmin \\
\hline Experimental & 44 & 80.3636 & 25.1670 & 88 & 72 \\
Control & 38 & 50.6316 & 28.7795 & 60 & 40 \\
\hline
\end{tabular}


The data, then, were tested for its normality and homogeneity as prerequisite testing. The normality test used Lielifors formula and the homogeneity test used Bartlett formula. After that, the data was analyzed by using the t-test for hypothesis testing. The results are presented in the following table.

Table 4

The summary of the t-test of hypothesis testing

\begin{tabular}{llllll}
\hline$t$-test & Degree of Freedom & Alpha & T-table & T-obs & Conclusion \\
\hline $\begin{array}{l}\text { Control and } \\
\text { experiment class }\end{array}$ & 80 & $5 \%$ & 1.9893 & 25.9157 & Ho is rejected \\
\hline
\end{tabular}

From the table 4 above, it is clearly seen that t-obs is higher than t-table. It means that there is a significant difference in students' achievement in literary history course between the experimental and control group. the students in the experimental group achieved better than those in the control group. In conclusion, the use of modern Indonesian literary history textbook (poetry in East Java) is more effective than the previously common textbook used by the lecturers.

\section{DISCUSSION}

Based on the results of interviews and observations with respondents, learning literary history with modern Indonesian literary history textbook (poetry in East Java) could increase motivation, active learning, and make students feel happy in learning literary history course. Learning literary history course with modern Indonesian literary history textbook (poetry in East Java) can make the time for learning efficient and make learning more effective because it contains specific materials compared to the previously common textbook used by the lecturers. Hutchinson and Torres (1994) argued that teacher claims that textbook could save the time, give direction to the lesson, guide the discussion, facilitate the homework, and make teaching easier, better organized, and more convenient. Further, Graves (2000) and Basturkmen (2010) also assert that one of the advantages of using textbook is that it provides a set of visuals, activities, readings, etc., which can motivate learners, it can save the teacher's time in finding or developing such materials. Lecturers as learning centers in learning activities play an active role in determining the textbooks used in the study of the literary history course. Powell and Anderson (2002) point out that the use of textbooks establishes a teacher-centered approach that plays a central role in lesson planning and the pace of progress. Meanwhile, Teacher's attitudes to textbooks are likely to have an impact on how they use them (McGrath, 2006). In case of previous related study, Suryaman, et al. (2013) carried out development research dealing with textbook material model of History of Modern Indonesian Literature based on Gender perspective. In this study, the researchers examined the development of a literary history textbook based on gender perspective, whereas in the research the writer conducted the research on developing literary history textbooks which specifically discussed poetry in East Java.

Modern Indonesian literary history textbook (poetry in East Java) is more effective than previously textbook that had been used in the study of the literary history course. This is evidenced by the results of the t-test. Modern Indonesian literary history textbook 
(poetry in East Java) was developed based on poetry in East Java, in which it can increase students' understanding of poetry in East Java. This textbook is effective since the content mainly focuses on the poetry and poets from East Java. It does not discuss too much and too large materials like the common textbook used by the lecturers previously. Besides, this textbook was developed based on the students' needs and was in line with the curriculum, syllabus, and lesson plan in Indonesian Language Education Study Program. Before this textbook was created, the series of stages had been done, i.e. needs analysis, development stage, expert judgment, limited try-out, revision, until the experimentation in the large scope. That is why it is no wonder if the textbook is valid and reliable, and also effective to teach literary history course in East Java Province, Indonesia.

\section{CONCLUSION}

To sum up, this study aimed at revealing the lecturers and students' perception on the use of modern Indonesian literary history textbook (poetry in East Java) in teaching Literary History course; and evaluating the effectiveness of modern Indonesian literary history textbook (poetry in East Java) in teaching Literary History course. The findings show that both the lecturers and the students from each university responded positively towards the use of modern Indonesian literary history textbook (poetry in East Java) in teaching Literary History course. They asserted that the textbook could motivate the students in learning literary history. Besides, the textbook can help the teacher to easily deliver the materials. Furthermore, from the $t$-test result, it can be concluded that the use of modern Indonesian literary history textbook (poetry in East Java) is more effective than the use of previously common textbook used by the lecturers to teach literary history. These findings should be taken into account by the lecturers of Literary History course while preparing and implementing appropriate textbook materials for teaching Literary History. This textbook is able to fulfil the needs of students and lecturers. This textbook was developed because it is in line with the current times and the more potential and creations of talented young people who continue to work to express all problems through their writing to help build and promote the nation. From these findings, conclusions, and implication, it is suggested to all related parties, especially lecturers of literary history, to always renew their teaching materials which could encourage students' motivation, students' curiosity, students' independence, and students' needs in order to create a good atmosphere in learning literary history.

\section{ACKNOWLEDGMENT}

This research was funded by the Ministry of Research, Technology, and Higher Education (Kemenristekdikti) of Indonesia through the Doctoral Dissertation Research (Penelitian Disertasi Doktor) in the year of 2017.

\section{REFERENCES}

Basturkmen, H. (2010). Developing courses in English for specific purpose. New York: Paglave Macmillan.

Boulton, M. (1993). The Anatomy of Poetry. New York: Holt, Reinhart \& Winston. 
Cunningsworth, A. (1995). Choosing your coursebooks. Oxford: Heinemann Educational Books.

Creswell, J.W. (2009). Research Design; Qualitative, Quantitative, and Mixed Methods Approaches (third edition). Newbury Park: Sage Publications.

Frankel, J. R., \& Wallen, N. E. (2012). How to design and evaluate research in education: $8^{\text {th }}$ Edition. Boston: McGraw-Hill Higher Education.

Graves, K. (1996). Teachers as course developers. England: Cambridge University Press.

Kennedy, X.J. (1986): An introduction to poetry: $6^{\text {th }}$ edition. Boston: Little, Brown and Company.

Litz, D.R.A. (2012). Textbook evaluation and ELT management: A South Korean case study. Asian EFL Journal. Retrieved from https://www.asian-efljournal.com/Litz_thesis.pdf

Hutchinson, T., \& Torres, E. (1994). The textbook as agent of change. English Language Teaching Journal, 48(4), 315-328

McGrath, I. (2006). Teachers' and learners' image for coursebooks. ELT Journal, 60(2), 171-180.

Noor, Riyadi. 2009. Panduan Penyusunan Buku Ajar dan dan Buku Teks. Bandung: Angkasa.

O’Neill, R. (1982). Why use textbooks? ELT Journal, 3(6), pages:.104-111.

Perrine, L. (1974). Sound and sense: An introduction to poetry. New York: State University of New York Press.

Powell, J.C. \& Anderson, R.D. (2002). Changing teachers' practice: Curriculum materials and science education reform in the USA. Studies in Science Education, 37, 107-176.

Reeves, James. (1972). Teaching poetry. London: Heinemann.

Rosidi, A. (1968). Cerita Pendek Indonesia [Indonesian short story]. Jakarta: Gunung Agung.

Rifai, M. (2010). Peningkatan motivasi penulisan perguruan tinggi [Increasing the motivation of academic writing in Higher Education]. Disampaikan dalam Lokakarya Penulisan dan Penerbitan Buku di Lingkungan Universitas Sebelas Maret [Delivered in a workshop of book writing and publication in Sebelas Maret University]. Surakarta

Sarwadi, S. (2004). Sejarah sastra Indonesia modern [Modern Indonesian literary history]. Yogyakarta: Gama Media.

Sastri, R. (2013). Indelible voice: Louise Glück, Poems 1962-2012. PN Review 210, 39(4). 
Sheldon, L.E. (1998). Evaluating ELT textbook and materials. ELT Journal, 42(4): 237246.

Siswantoro. (2010). Metode Penelitian Sastra [Literary Research Method]. Yogyakarta: Pustaka Pelajar.

Sudarmoko. (2009). Roman pergaoelan, penulisan sejarah, dan kanonisasi sastra [The romance of social, writing of history, and literary canonization]. Jurnal Humaniora Fakultas UGM, 21(1): 28-40.

Suryaman, M. (2012). Pedoman penulisan buku ajar [The guide of textbook writing]. Makalah. Jakarta: Pusat Perbukuan.

Suryaman, M. (2013). Pengembangan model buku ajar sejarah sastra indonesia modern berperspektif gender [The development of textbook material model for modern indonesian literary history based on gender perspectives]. Litera Jurnal Penelitian Bahasa, Sastra, dan Pengajarannya, 12(1).

Tarigan, H. G. \& Djago, T. (1986). Telaah buku teks Bahasa Indonesia [Evaluating Indonesian language textbook]. Bandung: Angkasa.

Triharti, W. (2010). Peran pusat perbukuan dalam penulisan dan penerbitan buku akademik [The role of the book center in writing and publishing academic books]. Makalah disampaikan pada Lokakarya Penulisan dan Penerbitan Buku Akademik [Paper presented at the Academic Book Writing and Publishing Workshop], LPP UNS.

Waluyo, H. J. (2010). Penelitian Pendidikan Bahasa dan Apresiasi Sastra [Educational research in language and literary appreciation]. Surakarta: UNS Press.

Wellek, R., \& Werren, A. (1990). Teori Kesusastraan [Literary theory]. Jakarta: PT. Gramedia.

Zalipour, A. (2010). Phenomenological studies of imagination in poetry: An introduction. 3L, The Southeast Asian Journal of English Language Studies, (1), 100119. 